Article

\title{
Research for the People, by the People: The Political Practice of Cognitive Justice and Transformative Learning in Environmental Social Movements ${ }^{+}$
}

\author{
Jane Burt \\ Environmental Learning Research Centre, Rhodes University, Makhanda 6139, South Africa; \\ jane.realife@gmail.com \\ + This quote comes from December Joseph Ndlhovu, a participant in the Changing Practice courses, who has \\ recently become a course facilitator. He stated that the best people to research the contexts of people who bear \\ the brunt of environmental injustice are those experiencing it and acting to change it.
}

Received: 27 March 2019; Accepted: 24 September 2019; Published: 12 October 2019

check for updates

\begin{abstract}
This paper describes how Changing Practice courses, developed by environmental activists in South Africa and based on social learning practice, have seeded cognitive justice action. For the educator-activists who facilitated these courses, it became apparent that we needed a bold emancipatory pedagogy which included cognitive justice issues. This enabled us and the activist-researcher participants to understand the extent to which local, indigenous, and spiritual knowledge had been excluded from water governance. The paper investigates how participants in the 'Water and Tradition' change project, established by the Vaal Environmental Justice Alliance (VEJA, engaged with cognitive justice, to demonstrate how African spiritual practice offers a re-visioning of the natural world. Finally, using the tools of critical realist theory, the paper reviews how VEJA bring about transformative social action through their participation in the Changing Practice course.
\end{abstract}

Keywords: cognitive justice; transformative environmental learning; social learning; African spiritual knowledge; critical realism; transformative environmental social action

\section{Introduction}

This paper explores the transformative capacity that emerged from a cognitive justice approach to transformative environmental learning. The context was the second iteration of a Changing Practice course for environmental activists in South Africa-part of a broader action research project, implemented by the Environmental Monitoring Group (EMG) and funded by the Water Research Commission (WRC) that investigated how civil society could monitor how South Africa's National Water Resource Strategy 2 (NWRS2) brought about water justice [1]. The 'change projects', which were part of these Changing Practice courses, became case studies in this broader research project.

In learning from the first course [2], I designed the second course by drawing on Freire-inspired critical and emancipatory pedagogy [2] which emphasizes how a learning process has to respond to the historical and material realities of participants, and at the same time take into account how the learning process itself is situated historically [3]. This approach led to generative moments where we, the facilitators and the participants, all had to engage with inequalities such as gender violence and exclusion, and the politics of knowledge-i.e., how knowledge is used to support the values and interests of the powerful in a neoliberal economy. In engaging with these issues, we began using the concept of cognitive justice in our learning praxis. These perspectives significantly changed the way we participated in the learning process, both as activist-educator facilitators and activist-researcher participants. 
In particular, the paper looks the 'Water and Tradition' change project, which was developed by the Vaal Environmental Justice Alliance (VEJA) an organization participating who had three participants attending the Changing Practice course. Their change project explored the relationship between African spiritual practitioners and the highly polluted Vaal River [4]. As will be seen, a focus on cognitive justice praxis as transformative learning led to VEJA seeding transformative social action in their change project and influencing the design of the course.

\subsection{Including Justice in Transformative Environmental Learning}

Humans have created an economic system in which people in rich countries consume ten times more of the world's resources than people in poor countries [5]. The way we use resources has led to what Elvis Komane, an activist-researcher on the Changing Practice course, calls 'ecological theft'. He made this statement at the Future Earth Seedbeds for Transformation Conference in Port Elizabeth held 9-11 May 2018. He was one of four activists who attended this conference. At this conference he spoke out boldly about the intertwining of inequality and environmental devastation, themes that come out of his organisations change project. There is a great need to transform this situation, and education and learning are seen as core mechanisms of transformation towards a more sustainable world.

However, David Orr writes eloquently about how Western educational systems and practices" equip people to become more effective vandals of the Earth" ([6] p. 5). Jickling and Wals ([7] p. 51) argue that education is only useful when we reflect on what kind of education we are engaging in, and for what purpose.

This section of the paper looks at how to include justice into environmental learning. Let us begin with a commonly used approach to environmental learning and see how it could be even more effective if situated within a broader social critique. A good example would be cultural historical activity theory (CHAT), which is useful and popular in environmental education. CHAT is a derivation of Vygotsky's research into childhood developmental learning [8], and its concept of expansive learning explores the co-constructing of the learning process through dialogue between the researcher/teacher and the employees/learners [9].

Engestrom defines expansive learning as the process through which an activity system (such as a particular work practice) resolves internal contradictions by "constructing and implementing a qualitatively new way of functioning for itself" [10]. This is achieved through broadening the shared object of work by explicitly (via the CHAT analysis) looking at the shared work task, tools, models and concepts of the activity, and identifying contradictions such that researchers and practitioners are able to construct new tools and models to overcome them.

Engestrom [9] points out that this process does not always lead to change, because once new tools or models are identified, an inertia often sets in. He suggests that the inertia is linked to identity formation- "After all, practitioners facing major transformations in work must somehow see themselves as individuals taking on a new personal identity, when the entire work activity is radically changed" [10], (p. 98). Gee (2003) argues that identity is a necessary component in all serious learning: All deep learning, he says — that is, active, critical learning —is "inextricably caught up with identity in a variety of ways. People cannot learn in a deep way within a semiotic domain if they are not willing to commit themselves fully to the learning, and such a commitment requires a willingness to see themselves via a new identity ([9] p. 36).

Carpenter and Mojab [3] query whether expansive learning makes it possible to resolve intractable internal contradictions, and argue that there is a limit to which models and tools like CHAT can address deeply embedded inequalities (both contextual and historical) and the politics of knowledge generation. Nevertheless, expansive learning theory can contribute much that is useful for a more transformative approach to learning, i.e., its process of intervention, its identification of contradictions, use of dialogue and collaborative engagement, and generation of new models and tools for experimentation.

How then to integrate social critique with expansive learning? Social movements have a long history of learning [11-18], leaving a legacy of adult learning and social movement learning or popular 
education. Some approaches to adult learning that falls outside of social movements has been criticised for losing their political edge, and for being reduced to a methodology without the commitment to liberation that made the work of these thinkers so effective [8]. Environmental education has also come under such criticism, with demands for a movement closer to addressing social inequity and injustice $[15,17,18]$. This has led to a resurgence of Freirian educational theory and postcolonial theory to be included in environmental education, as well as (for me) the exciting prospect of introducing ecofeminism $[19,20]$ into learning for transformation.

There have been calls for the environmental sector to reconceptualise transformative learning to include transgressive learning, defined as learning that "intentionally generates critical thinking and collective agency and praxis that challenge factors that have become normalized" ([21] p. 51) but have to be challenged vigorously for substantive sustainability transformation. Examples would be colonial practices, or gender and race relations [21].

Such approaches to learning are not common within the sustainability movement, where environmental risks to the planet are usually separated out from issues of justice and inequality. Expansive learning may lead to transformations within a work environment or lead to a new understanding about complex issues, but neither of these necessarily challenge normative practices. Lotz-Sisikta et al.'s [21] paper poses two useful questions about the purpose of education-Is it transformative and transgressive, and how? Answering 'how' reveals the transformative capacity that is generated for and by an educator-activist and activist-researcher. I have explored this in some detail in Burt et al. [22].

I would argue that much of the transgressive learning we need can be found in the way popular education happens within social movements [11]. In social movements the divisions between educator and activist are blurred, because activists are educators, and professional educators who work with activists are themselves activists who situate themselves within the social movement. Popular education is thus overtly political, in both theory and practice, engaging with questions and contradictions coming out of social action being thrown up for dialogue and analysis, action and reflection (praxis) [23]. Needless to say, such engagement cannot be extracted as a 'method' to be used outside its political-activist context. I emphasise this by referring throughout this paper to facilitators and educators as 'educator-activists' and to participants in the change projects as 'activist-researchers'.

This paper uses a case study to show how the Changing Practice course has been an example of the effective incorporation of cognitive justice into transformative learning, in two ways:

1. Activist-researchers' work in the Changing Practice course shows how engaging in cognitive justice throughout the course, and in the development of their change projects, was transformative and transgressive. The Vaal Environmental Justice Alliance case directly and explicitly challenges certain aspects of society that have become normalised.

2. Activist-researchers learned to act and reflect on how their work can transform their practice based on issues that activist researchers raised. This contributed to both the theory and practice of their learning, and to the theory and practice of cognitive justice.

I also demonstrate, through the example of the VEJA case, how cognitive justice praxis is core to transgressive learning practice.

Below, I briefly explain what educator-activists and activist-researchers mean by cognitive justice. I then introduce the methodology I used to investigate the VEJA change project and how it engaged with cognitive justice, leading to transformative action both within their change project and within the Changing Practice course.

\subsection{What Is Cognitive Justice?}

In this section I explain the concept of cognitive justice and how we came to engage with it as educator-activists and activist-researchers. 
The term cognitive justice was developed by Visvanathan as a response to how Western science (and the products of Western science) can become transferred in ways that lead to violent consequences, such as the forced removal of thousands of people to make way for the building of a dam ([24] p. 87). Visvanathan maintains that the fundamental violence built into Western science is revealed when the majority of people in the Global South are degraded to the status of consumers of knowledge generated in other contexts, and denied their rights as creators of knowledge.

Visvanathan advocates firstly that knowledge should be engaged as a parliament of epistemic debates, and secondly that knowledge systems are ecologies that need to be given space to thrive as active practices ([24] p. 93). Other activists and scholars have taken up the cognitive justice concept, showing how the legitimation of Western knowledge often involves an act of seizing power in the intellectual sphere by belittling or ignoring the knowledge held by diverse cultures and countries in the Global South [25-31]. This seizing of intellectual power often includes the domination of mechanisms of knowledge generation such as the media, universities, internet resources, and professional institutions [31-34].

Cognitive justice has become an important generative concept in the Changing Practice courses in the water sector in South Africa. My own exploration of its relevance began with witnessing the need of participants in these courses to find a way of articulating the violence of the politics of knowledge [26,27,35]. I realised that I had been for a long time unwittingly assenting to such violence because of the nature of the institutions to which I belonged, historically linked as they were to colonialism and apartheid. Visvanathan's theory of cognitive justice provided a basis in which I, and others involved in the Changing Practice courses, could gain some perspective and include knowledges that are not heard or recognized in professional and government contexts. I first introduced the concept of cognitive justice into the Changing Practice course when I was facilitating a module on 'knowledge networks' (February 2015). We were discussing with activist-researchers how to access or create networks of knowledge, and the activist-researchers spoke about how they had long been excluded from certain networks. They later took this awareness to other contexts such as the Forum of Forums indaba. This was a research project funded by the WRC that looked at how to revitalize catchment forums in South Africa. Catchment forums were designed under the 1998 National Water Act [36] for civil society participation in water resource management, and the research project reviewed the establishment and functioning of forums throughout South Africa. The research culminated in a two-day 'Forum of Forums' indaba where various stakeholders gathered to discuss what was working and what was not working in catchment forums. Besides academics, government officials, activists and NGOs, there was a strong representation in the indaba from the South African Water Caucus, including participants from the Changing Practice course. The Changing Practice participants used their research to object to the way poor communities and African spiritual water users were excluded from forums because of the narrow forms of knowledge shared. In addition, they asserted, catchment forums were dominated by large scale water users and difficult to access, as meetings were often in cities and in expensive venues [37].

One criticism of cognitive justice has been that, in its attempt to value local and indigenous knowledge systems, all knowledge becomes viewed as relative or, alternatively, that Western science reduces the reality of indigenous knowledge to a quaint pseudoscience in which cultural practices become false explanations. To counter such criticism, I found it was effective to draw on critical realism, a theory which offers a way to engage with indigenous and spiritual knowledge without prejudice [38]. The layered nature of critical realism accepts that the non-empirical is real-so absences are real even though they cannot be measured (an example being how the absent past shapes the present). According to critical realism, solely empirical explanations provide shallow understanding of events because they do not include or reveal all the mechanisms that make an event possible [38]. Thus, we can describe a river in terms of water chemistry, or as a habitat for particular species, or as a hydrological system. Each of these explanations reveals much about the river but none of them explain the underlying interconnectedness between living beings that make the river essential for human life. 
Leigh Price ([38] p. 345) calls Western science's inability to take indigenous axiology seriously 'effectively racist' in that it takes its own superiority for granted. Critical realism, on the other hand, sees mechanisms and structures as emerging out of empirical levels of reality, and so connects all phenomena to the real. Critical realism thus embraces epistemological relativism, allowing a diversity of explanation which does not take away the reality of the mechanism. Our explanation for the interconnected web of life can vary from our relationship with God, to honouring our ancestors, to systems thinking. Incorporating critical realism with cognitive justice into our educational practice strengthened its transgressive possibilities.

The conceptual framing presented above is meant to provide background on how we applied cognitive justice in the particular Changing Practice course described below. This paper does not attempt an in-depth overview of cognitive justice theory and practice as applied to the Changing Practice courses in general, although this has been done elsewhere ( e.g., [39]).

\subsection{The Changing Practice Courses}

In 2014 the EMG, together with the SAWC, began a social learning and action research project funded by the WRC. The purpose was to strengthen civil society's monitoring of the NWRS2 by testing social learning approaches to capacity building. Some work had been done on this in a previous WRC Changing Practice course run through the Environmental Learning Research Centre (ELRC) Rhodes University [2]. This time, however, the Changing Practice course was embedded within the SAWC social and environmental movement. It gave the research team an opportunity to test a collaborative action research and social learning approach towards the realization of participatory democracy [1].

This was a radical approach for an established research institution like the WRC to be funding. It allowed participants on the course to respond to broader research questions of the WRC study as well as feed into and inform the SAWC's own campaigns and priorities. The project was ambitious-to understand the role of civil society movements in the monitoring of policy, to strengthen these movements, and to see how social learning could inform monitoring activities, while at the same time strengthening the member organisations of the movement and its network as a whole [1].

Changing Practice courses are designed as four or five iterative cycles of learning (See Figure 1). Each cycle consists of a working together session and a working away session, in which participants concentrate on their change projects in their home environment. The change projects include generative themes [1] (developed through the guidance of dialectic questions posed by the course) that participants bring back to the Changing Practice course, and for which learning is designed and facilitated. In this way the course content and learning methods change with each cycle, depending on what emerges from the change projects. The process is a continual back and forth weaving which requires care and reflexivity on the part of the facilitators. This flexibility made it possible to foreground cognitive justice in the course design and practice.

Changing Practice courses require facilitators to carefully (and care-fully) situate themselves in relation to the work of the participants. The facilitators have to know how to build relationships, be alert to generative moments, open opportunities for knowledge existing in living networks, notice and mediate multiple forms of knowledge, create access for activists to professionals and professional institutions, and engage in multiple levels of care work [36]. The facilitators have to see participants as experts in their own right, and allow participants' knowledge, some of it generated through their change projects, to influence them and the ongoing design of the course. 


\section{Assignment 4}

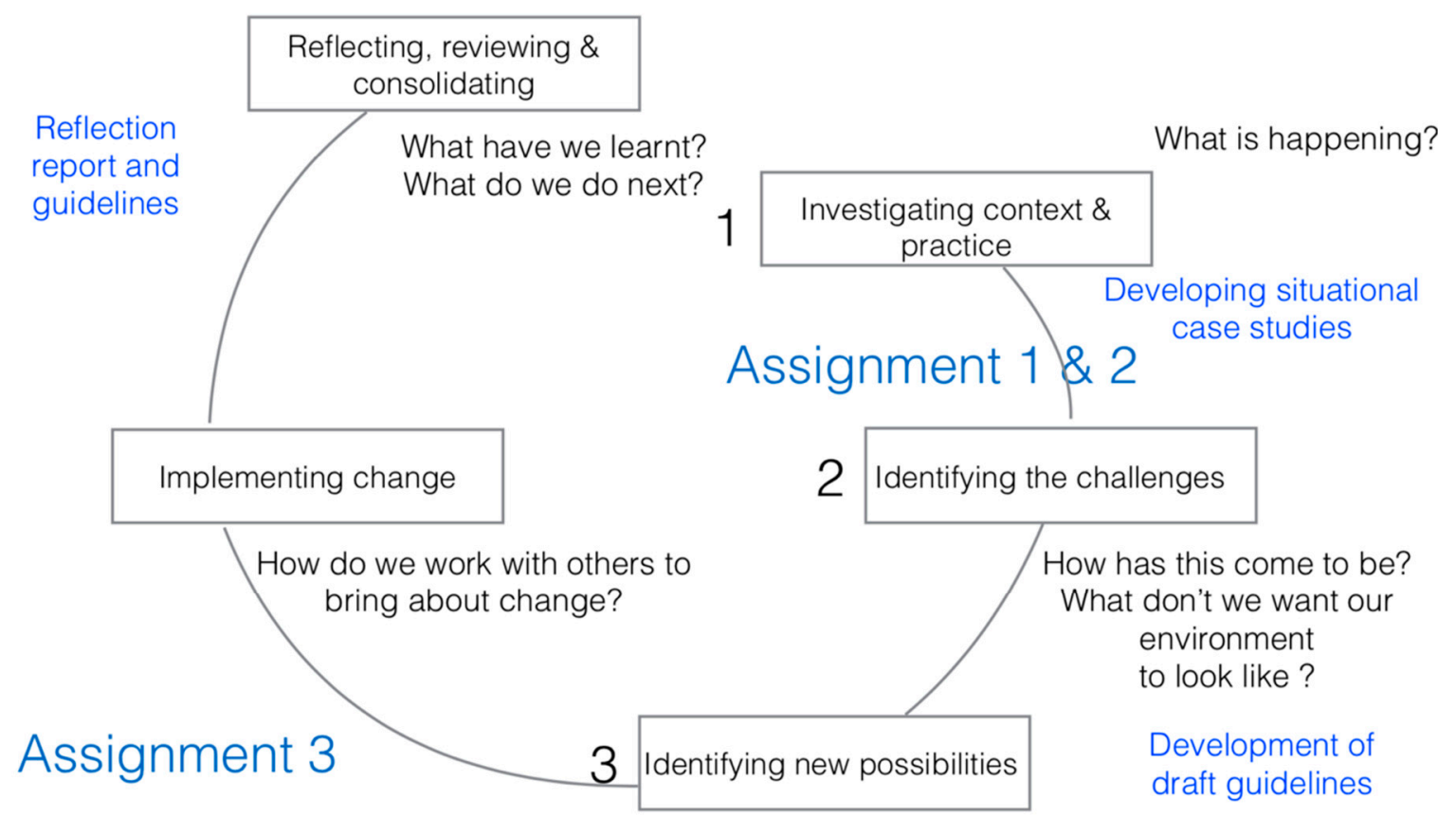

Engaging \& supporting

How and at what level, can we bring about change? civil society practice

Figure 1. The design of a Changing Practice course with change project assignments.

\section{Materials and Methods}

\section{Critical Realism and Transformative Social Action}

In this section I outline a critical realist approach to transformational social action, called the transformational model of social activity (TMSA), [38,40-44] which I use to underscore the Changing Practice course educational approach. TMSA provides a theoretical basis for showing how cognitive justice social action can be enabled by the Changing Practice courses.

Critical realism, as explained by its leading theorist Roy Bhaskar, is an ethical philosophy that argues that a correct way of seeing the world leads to the correct way of acting in the world [45]. According to Bhaskar, Western philosophy conflates epistemology and ontology, and therefore speaks from an unsound ontological position which inhibits radical change [45,46]. In a further development of critical realism, which he called dialectical critical realism, Bhaskar identified another hiatus in Western philosophy, namely that it speaks of reality in terms of positive qualities and tends to be silent about negative qualities which he refers to as gaps and absences. For Bhaskar this means Western philosophy has a limited view of real change, because if reality only consists of positive qualities, then change can only be a redistribution of these qualities rather than an absenting of qualities or the filling of gaps $[24,41]$. This way of seeing has significant value for how we look at indigenous, local, or spiritual knowledge. Most forms of spiritual knowledge include an ethic of care for the environment, the absence of which means a real gap between the ability to know and the ability to act ([38] p. 348).

I have found, in the Changing Practice courses, the critical realist epistemological dialectic $[40,41]$ to be of great help in articulating the transformative learning process, because it sets out moments where 'absences can be absented' and thus new knowledge generated. I have described this ([39] p. 14) as a sequence of changed perspectives:

- From 'it is happening' to 'what is happening?' (absent the absence of acknowledgement that there is a problem, rather than assume the status quo to be normal) 
- From 'what is happening? to 'how can this be?' (absent the absence of an explanation for the problem)

- From 'how has this come to be?' to 'how can this be transformed?' (absent the absence of action to address the problem)

A critical realist approach to agency acknowledges that we are all born into structure. We have no choice about the context into which we are born, but this does not mean that we cannot influence our context. All human beings have agency and every act is agentive. The issue is whether such agency reproduces structure or whether it transforms it. As Bhaskar puts it, "Society is both the ever-present condition (material cause) and the continually reproduced outcome of human agency" ([47] p. 37).

Bhaskar describes dialectic engagement as agency in four dimensions or planes [40]:

- Material transactions with nature: this refers to transformations at the level of personal and collective interdependence with species, habitats, landscapes, the planet, and even the cosmos ([48] p. 6).

- Social interactions between people: seeing relationships as a core ingredient for action, and acknowledging that individuals and social systems cannot be reproduced or transformed without social interactions ([41] p. 6). Social interactions between people are described by Bhaskar as on a continuum between the two poles of enabling, which Bhaskar refers to as power one (power as transformative capacity-'power with') and oppressive, which he calls power two (power as oppressive as in a master-slave relationship-'power over') [40]. We have the choice to reproduce oppression or move towards transformation in enacting our relationships.

- Social structure: although social structure precedes agency, the form that social structures take is dependent on what we have done and what we will do.

- The embodied personality: an individual is an embodied historical, feeling and thinking being. There are many ways in which individual freedom can be suppressed-human bodies can be incarcerated or treated with disrespect, ways of thinking and knowing the world can be unequally valued, individuals do not have the same access to education. Transformative action attempts to free the body from health risks, free the mind through more open ways of thinking, and heal psychological conditions such as lack of confidence or sense of inferiority-all of these being constraints that can inhibit action [40].

These four planes of being should not be viewed as staggered on top of one another but, as Bhaskar prefers to see them, like a cube ([40] p. 54). For transformative social action to succeed, there must be an absenting of obstacles to transformation at all four of planes of being.

If we as environmental activists take seriously the common assertion that we are all learners, critical realism gives us the tools to educate and transform our practice and transform how we think and practice learning. Carpenter and Mojab [3] write that what is required in adult education is a dialectic analysis of the injustices we want to change as well as an openness to our learning process that needs to be continually questioned in the light of the contradictions of the social, cultural and material world.

When a participant unearths one of these contradictions through direct experience, whether via anger or contemplation, the learning moment has to expand to embrace this. As facilitators we have to be willing to delve into these contradictions. I have found that the critical realist dialectic as a facilitation practice, within an understanding of the TMSA, unfailingly opens a way to deepen my own transformative educational practice.

We turn now to the VEJA case as an example of how cognitive justice was applied. 


\section{Results}

\section{1. 'Water and Tradition': A Case Study of the VEJA Change Project}

"We began to understand the moral value of cultural religious groups' practice based on natural water" ([4] p. 1).

The Vaal Environmental Justice Alliance (VEJA) has for many years been involved in a community monitoring programme of the Vaal river system, one of the most polluted in South Africa [42,49]. The VEJA community monitors found that traditional healers and African churches were practising their rituals in the river system, including in some of the most polluted parts. This was of concern to VEJA as no representatives from these religious groups had attended the catchment forums where information about pollution is shared. The catchment forums are the formal channels for stakeholders to raise their concerns with the Department of Water and Sanitation.

As their change project in the Changing Practice course, VEJA participants wanted to investigate how spiritual water users (a term they coined) could be seen as valuable custodians and water users, on an equal footing with agricultural and industrial users of water. They wanted to know why spiritual water users were not participating in water governance forums, and what prevented them from participating. In their change project booklet VEJA wrote that "We argue in our case that spiritual water users are custodians of our rivers, fountains and dams and therefore should be involved as monitors of our water. We also advocate that spiritual water users, like other citizens of South Africa, should have the right to access clean water for their spiritual practice" ([4] p. 5). As Samson Mokoena put it, "South African policy doesn't see religion as a water management practice, and I think that's where it fails. It talks about mining, industry, agriculture, but not about culture, tradition and religion"(VEJA mentorship meeting, 2015).

The water system of the Vaal River, which supplies the water needs of households and industries in Gauteng, has been devastated by human economic practices, with profound effects for the millions of people who live in the Vaal Triangle. The spiritual healers and African Christian churches explicitly honour the river as a home of the ancestors. They consider humans to be visitors who should treat their hosts' home with respect. Their interactions with the river are fundamentally non-destructive, and their religious practices are geared towards nurturing human well-being and build connections to community life that help people deal with difficulty. Thandiwe Ngcanga points out that African churches are places where women go to receive and offer emotional support [4].

While the Vaal's spiritual water users cause negligible environmental damage, the damage caused to them by pollution is more than physical, it extends to the psychological and spiritual. Patricia Mdluli, a traditional healer on the Changing Practice course in the Mpumalanga Water Caucus describes how commercial timber plantations upstream have reduced the water flow in the rivers in Bushbuckridge, Mpumalanga so severely that some sacred places are "dead". By this she means that the ancestors have actually departed from their river home, and the river has lost its spiritual value. Yet Patricia still goes to these sacred spaces to honour what they once were. She writes of the loss of a way of being in the world, one that has been eroded and replaced with a way of life that values the natural world solely as an expendable material resource [50]. A VEJA course participant, Samson Mokoena, wrote about how spiritual water issues are affected by broader issues of land ownership in South Africa-having limited access to the river, and often confined to the more precarious parts, to places where people have been washed away and drowned [4].

Mduduzi Tshabalala and Thandiwe Ngcanga write about how the Vaal spiritual water users are suspicious of government bodies like the catchment management forums and shy away from researchers, viewing them as people who have come to steal their knowledge (as has indeed happened in the past). There is much suspicion, and past actions of researchers and governments towards communities have broken down trust [4].

In the first stages of their change project, the VEJA activist-researchers immersed themselves in the river's spiritual practices by attending churches' ceremonies and spending time with sangomas 
and spiritual healers. They acknowledged these experiences as valuable forms of epistemic justice (the value of one's knowledge being heard) [51] and brought these perspectives to the Changing Practice course. The facilitators in turn acknowledged the validity of a spiritual way of engaging with the river ecosystem (Documented in the minutes of Changing Practice module 2, February 2015) (Figure 2).

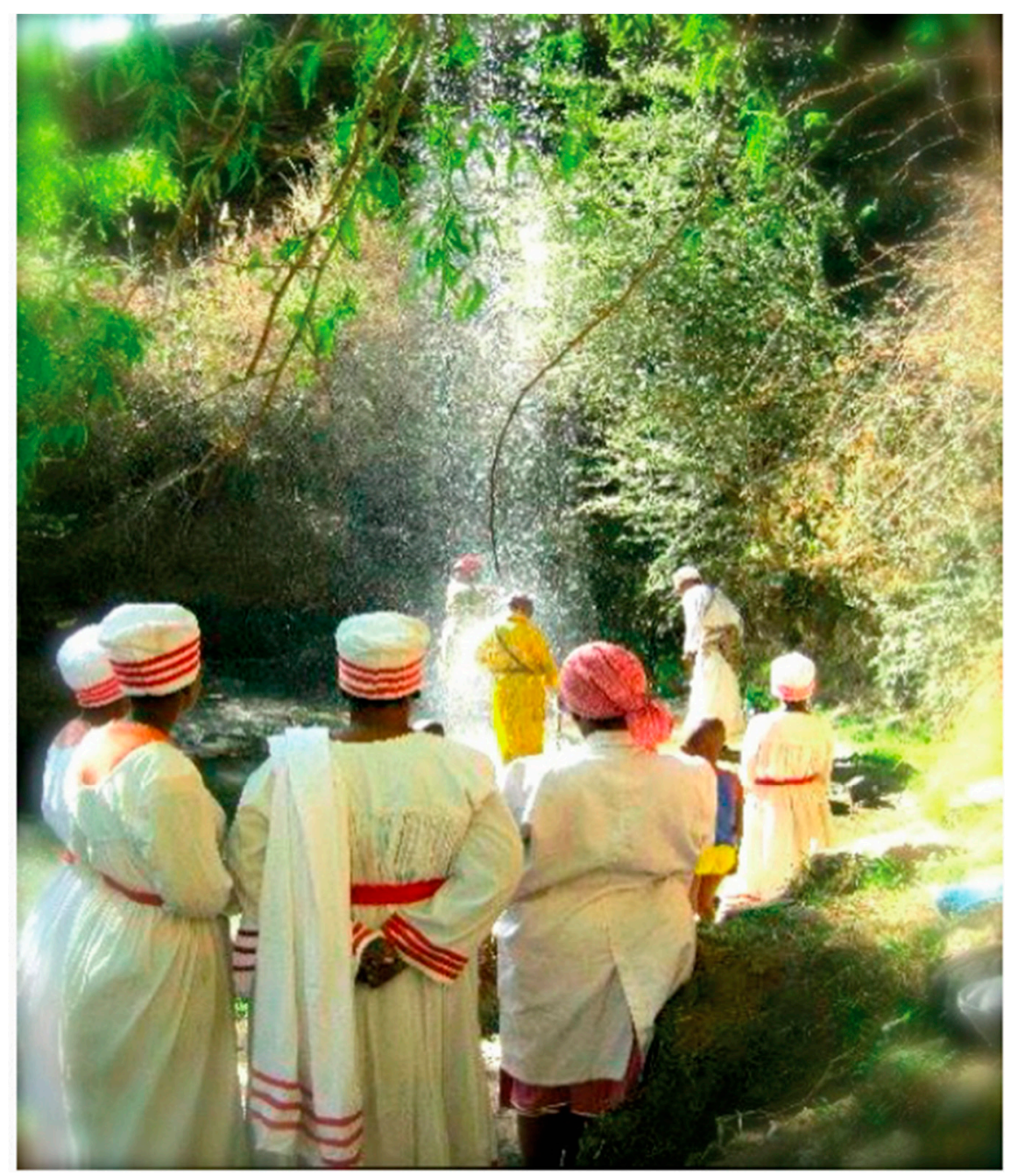

Figure 2. African church members engaged in spiritual water practice. Photo @Thandiwe Ngcanga.

Although the VEJA participants made the effort to be physically present in African spiritual practices, they realised that the relationship between the knowledge systems of African spirituality and the knowledge systems of water managers would take a long time to bridge. They knew the spiritual water users were not willing to be involved with university research, which they associated with oppression and knowledge-stealing. To overcome this impasse, VEJA decided to engage with the spiritual practitioners through their formal healer organisations, which are recognised by the government as valuable and significant institutions of knowledge. The healer organisations already had affiliations with the Department of Health and with NGOs supporting people with HIV/AIDS, and were willing to ally with VEJA after the dangers of pollution in the Vaal river were explained to them.

VEJA put their case at the South African Water Caucus (SAWC) and Department of Water and Sanitation (DWS) dialogues.The South African Water Caucus (SAWC) and Department of Water and Sanitation (DWS) dialogues were held as part of the WRC-funded action research project. The aim was to feed-back research done by activists, reinitiate regular meetings between the department and 
civil society groups like the SAWC, and to work with the SAWC on guidelines for the participation of civil society in water governance) that were part of the broader WRC research project. At this meeting, Samson Mokoena called the high levels of water pollution in the Vaal system and the lack of enforcement 'a genocide'. Department officials responded by citing the water law and policy which provides a space for all citizens to engage with water governance. The VEJA participants had come prepared for this response, and related incident after incident showing how the policy was failing in practice.

At the same meeting VEJA also made a strong argument that spiritual water users had been excluded. The department officials responded that spiritual water use fell under the category of recreation users, which would make them eligible to attend the water forum meetings. VEJA explained, in turn, that it was not eligibility that excluded people, but more fundamentally the knowledge system on which government policies and laws are based-a knowledge system that sees the river as a resource to be used and not as a sacred space to be honoured. Other Changing Practice participants added their voices about other kinds of exclusion. They spoke of how water knowledge was communicated with cultural bias-in English, and in technical language, via PowerPoint presentations. They also spoke of how large scale industrial and agricultural users dominated and controlled both the decisions and the narrative about water use (SAWC/DWS dialogues, October 2015 and the Forum of Forums workshop [37]).

Some department officials nodded their heads. Most of them came from similar traditions and belonged to an African church, or at least grew up knowing that rivers were the home of the ancestors. Some younger officials expressed their sadness to hear how policies that they believed in had become distorted in practice. Some even admitted that the department was struggling and their ability to act was limited.

Although this meeting did not lead to any immediate changes, it did regenerate a relationship with DWS that had been broken. A fragile understanding had been built through the passionate expressions of frustration, and a willingness from both parties to hear each other. But much distrust remained. After the meeting, VEJA continued to build their relationship with the traditional healers' institutions.

The traditional healers agreed to join the SAWC and were present at the next SAWC/DWS dialogue meeting (Minutes of SAWC/DWS dialogues, February 2016). They also started attending the local catchment management forums. With their collaboration, VEJA used their change project to draw up a proposal and apply for funding from the Human Rights Commission to continue developing their case. In 2018, both VEJA and traditional healers gave evidence to the Human Rights Commission of Inquiry investigating whether government negligence in industrial regulation non-compliance in the Vaal Triangle could be viewed as a human rights violation. At the date of this writing, January 2019, this inquiry is still ongoing. The VEJA case had raised the plight of the Vaal river to a national level.

\subsection{The VEJA Change Project and How Cognitive Justice Led to Transformative Action}

VEJA's arguments are important lessons about how cognitive justice can work in both learning practice and activist practice. The VEJA activist-researchers identified key issues that needed to be absented if cognitive justice, and thus environmental justice, was to prevail. We now revisit the three dialectic transformative moments of the critical realist epistemological dialectic and describe how these were applied by VEJA to generate their change project.

From it is happening' to 'what is happening?'

The Changing Practice course introduced concepts and skills to help activists define the context of their concerns.

From 'what is happening? to 'how can this be?' (absent the absence of an explanation for the problem). 
The course guided VEJA's awareness of what was happening by asking how this came to be, in the light of history and context. The facilitators introduced the idea that knowledge systems are relational like ecologies [52] or parliaments [53] and exist in networks. Activists were encouraged to practice the skills of engaging with different forms of knowledge to broaden their understanding. They reviewed all the local knowledge they had gathered and came up with a series of questions for further exploration which they generated through mapping exercises at multiple levels.

From 'how has this come to be?' to 'how can this be transformed?' (absent the absence of action to address the problem).

Through the course, VEJA participants decided to test what could be transformed by presenting their work publicly. The course then introduced skills of how to develop arguments from evidence, how to interrogate relationships, and question whether existing relationships can be strengthened and developed.

VEJA articulated three themes related to cognitive justice in their change project.

\subsubsection{How Spiritual Practices Are Affected by the Polluted Rivers}

What Is Happening?

For VEJA, this moment was the realisation that the dire water pollution issues in the Vaal were affecting not only people's physical health, but also their spiritual well-being. They realised that treating rivers purely as resources was not a view shared by all people. Through the first cycle of learning, VEJA immersed themselves in the spiritual practices of their community (Samson Mokoena literally so, by taking part in a baptism ritual on the banks of the Vaal river). They came to understand how independent African churches and traditional healers perceived rivers as homes of the ancestors who they could visit for healing and wisdom.

\section{How Can This Be?}

To try and answer questions arising from their investigations into their local context, VEJA participants read published research, spoke to organisations and government officials, and looked at websites. Through this process VEJA began to see more clearly how pollution in the Vaal river was affecting the spiritual water users, and how they had been excluded from water governance. Samson linked this exclusion to the vested interests of capitalism and colonialism, the introduction of Christianity, and particularly the role of women in spiritual life. Their reading of a paper by anthropologist Penny Bernard [53] helped them to articulate how African spiritual knowledge is excluded from the river.

How to Transform?

Mduduzi Tshabalala, when asked to reflect on how the change project had developed between the first and second assignments, said that VEJA was becoming more resourceful. "The team is learning how to find more knowledge, how to get advice, and how to approach people. We are also more confident." He gave an example: "We go to present the project itself, maybe let's say to the forums, we have already done the research, we know what we are talking about ... we have the evidence that the practice exists, and it is not given much acknowledgement." (Interview with Mduduzi Tshabalala, June 2015).

Mduduzi felt the assignment questions that guided the change project helped him. He was also encouraged by the way the group were continually asked to clarify their questions. He said, "I think it is a skill to develop a question and go to talk to somebody about it." (Interview with Mduduzi Tshabalala, June 2015). He expressed how the process had helped him to a greater understanding of African spiritual practice. "I know how important water is for them. So, it becomes more meaningful what we are doing. It is something that is worth it." 
VEJA's change project was one of four presented at the Department of Water and Sanitation (DWS) and South African Water Caucuses (SAWC) dialogues. A practical point that VEJA raised was that DWS did not have a way of liaising with spiritual water users. To overcome this, VEJA proactively decided to use the methods of the Changing Practice course to run their own mini-course with spiritual water users and motivate them to become involved. This led to a successful request for funding from the Human Rights Commission which they used to deepen their case and present it at the Human Rights Commission hearings. Mduduzi called this presentation 'the most exciting adventure of the research" and wrote "The achieved evidence thus far proves the need to address issues of the spiritual water users as valuable in a democratic and developing society." (Interview with Mduduzi Tshabalala, June 2015).

\subsubsection{Relationships have been Broken Down by Past and Current Inequities}

\section{What Is Happening?}

VEJA learnt that spiritual practitioners had had bad experiences of researchers taking their knowledge and publishing it without permission, and so were suspicious of researchers. Traditional healers were also suspicious of government officials who they saw as having abandoned a spiritual morality in relation to rivers.

Having participated in catchment forums, VEJA did not have the same suspicions of government, but they too struggled to engage with DWS officials. Consultation and contact between government and civil society had been deteriorating over recent years. The SAWC used to have regular meetings with the minister of Water and Sanitation (then the Ministry of Water Affairs). This no longer happened, which was partly why the Environmental Monitoring Group had asked the WRC to explore and support civil society monitoring of the National Water Resource Strategy 2.

\section{How Can This Be?}

In Mduduzi's first assignment, he quotes a sangoma as saying, "I believe that my practice has nothing to do with business or anything else but cultural fulfilment. The bureaucracy will never teach us the right customs of doing or practising our culture or tradition, which is why we have our own traditional schools." (Mduduzi Tshabalala's first assignment, 2014). Traditional healers were disturbed by how industries are allowed to operate in ways that damage water. As one traditional healer said to Mduduzi, "Yes, we are aware of these users [industrial polluters], doing all the wrong things and taking the water and doing whatever they are doing with it. These people must be taught the proper ways of interacting with the natural resource, because once one enters into the premises of the holy waters they must know that they are also visitors there and therefore must respect the owners [the ancestors], they must know all the proper ways of interacting. And there will be a time whereby the owners of the resources will be angry, and things may turn into a catastrophe." (VEJA pre-course assignment, 2014).

How to Transform?

VEJA found that working with organised groups of spiritual healers and religious leaders was more fruitful and less secretive than working with individual healers. This was because the healers felt protected by their organisation, which gave them a sense of collective power. For their part the healer organisations were very interested in working with VEJA and already had relationships with the Department of Health. They quickly understood the link between health and polluted water.

VEJA found interactions with government officials and government-engaged consultants to be much more difficult. This was mainly because policy and law consider the river a resource, and so a complete negation of the spiritual users' perspective. VEJA had to develop a strategy of how to work in such inaccessible government environments. Samson explains it as "participating on our own terms where we develop our own agenda within their agenda" (Module 1 minutes, September 2014). 
VEJA teams now meet before they go to a formal meeting like a catchment management forum. They decide on their own agenda, regardless of the official stated agenda. They decide what information they want to get out of the meeting and identify their objectives for attending the meeting. I witnessed how this worked with the SAWC coordinating committee of which Samson is a member, and which adopts the same strategy. Before a meeting with the DWS, they discuss their experiences of the previous meetings and what was achieved, if anything. Then, they decide on a joint strategy for the coming meeting regardless of the official agenda. This does not mean that they disrupt the meeting, but they know in advance what they want to get from it.

VEJA's communication with individual government officials in charge of the Vaal river system was equally difficult. Mduduzi's strategy was to attend meetings where he knew municipal managers would be and seek them out during tea breaks to express his ideas and glean information. VEJA's strategy was to build alliances where possible but not to compromise in their stand that the current situation in the Vaal was unacceptable. They were unable to transform, at a structural level, the contradictions that made it difficult to engage with government officials, but they were able to navigate this because of their understanding of why government departments were difficult to engage with.

\subsubsection{Women Do Not Have the Same Freedoms as Men}

What Is Happening?

Gender dynamics surfaced unexpectedly during the research phase of VEJA's change project when Thandiwe experienced a painful encounter with sexual harassment. It happened when a man who was supposed take her to interview a pastor instead took her to an isolated area where, as Thandiwe put it, "he started his funny business".

\section{How Can This Be?}

Thandiwe's statement was a turning point for the group and facilitators. Among other things her experience made the group realise that being female could limit someone's ability to do research on her own. Women in the group started talking about how men often spoke for them. Samson, in his change project, noted significant gender differences in the African churches- that they were always led by men, and that women had to practice at a different part of the river. At the same time, he noticed, the majority of traditional healers were women.

\section{How to Transform?}

VEJA's work on gender became a catalyst for the SAWC to better monitor the silent issue of gender in the caucus. SAWC set up a facilitated gender dialogue with its coordinating committee, which encouraged members to tell their own experiences of gender dynamics. Women expressed how they felt men spoke for them at SAWC meetings and how men and women were treated differently when they presented ideas. They mentioned how men held meetings by themselves without inviting women to participate. Both men and women reflected on the strength of their mothers and the power of women who had cared for them when growing up.

The dialogue led to a working document on gender being developed for the SAWC, and a principle on gender equality being added to the SAWC principles. It was acknowledged that this was only a first step, that there was still much resistance to talk about gender issues and the deeply entrenched attitudes to women in South African society. There was a call to think further about how gender and race discrimination are linked to class structures in capitalism [8], and also to environmental degradation.

\section{Possibilities for Transformative Social Action Catalysed by the VEJA Change Project}

The VEJA change project catalysed transformative capacity in the Changing Practice course itself, as well as within the social movement and beyond. This section is a more detailed description of the 
third moment of transformation-from 'how has this come to be?' to 'how can this be transformed?' It addresses our agentive power in the world.

\subsection{Catalysed Agency at the Four Dimensions of Being}

Using Bhaskar's four dimensions of being, VEJA's change project narrative could be called an interweaving of agency and alienation from agency. To explain this with an example: It is common for Changing Practice course participants to be people who have low self-confidence, having been educated in a system that does not acknowledge that their cultural knowledge has any value at all. In Bhashar's terms, what then needs to be absented is the inability to hear the value of spiritual practice, cultural knowledge and non-normative ways of being by the education system as a whole. For the facilitator, this means drawing on theories that explain why we can and should value spiritual and indigenous forms of knowledge.

Bhaskar shows that not conflating epistemology and ontology enables us to explore real mechanisms in multiple knowledge forms [45]. So, for example, the act of valuing the environment as being more than a resource for consumption is a condition for developing empathy for a polluted river, which in turn is a condition for environmental action. By accepting such epistemic relativism we can understand that the value expressed as 'spiritual practice' has meaning for the relationship with a river for all of us, whether or not we are religious or African To understand this, let us look at the process of absenting whatever inhibited transformative agency in the VEJA change project.

4.1.1. What Did We Absent at the Level of Material Interaction with the World through the Changing Practice Course and the VEJA Change Project?

Through the Changing Practice course and VEJA's change project we understood that knowledge is not a commodity which can be passed from one person to another, but rather a vibrant expression of being that emerges out of our connection with ourselves, with one other, with our institutions and with the living world. The Changing Practice course was developed in a university context where spiritual knowledge was not primary at all, unless perhaps when it was an object of study. But, as Bhaskar experienced when he began to explore spirituality in his work, drawing on spiritual knowledge in such a context is taboo, because it is not associated with empirical evidence. Nevertheless, Bhaskar argues, the underlying mechanism of faith is an" awe-inspiring awareness of the interconnectedness of all things and associated with creativity" ([38] p. 341). This is not very different from values held by many environmental educators, which are currently re-emerging in the academic world as 'complexity thinking' or 'systems thinking.' Spiritual traditions reach their explanations not by conjecture, but by intense observations of human nature, noting patterns, structures, or mechanisms to explain events ([38] p. 343).

For us facilitators, our educational experience in school and university had taught to be wary or hesitant about spiritual knowledge. We now had to take this same hesitancy and absent it from the educational space of the Changing Practice course. It was a salutary lesson in how silencing one perspective of the natural world led to the dominance of another perspective, one that saw that world as nothing more than a material resource. VEJA used their change project to insist that the knowledge of traditional healers and other spiritual practitioners be allowed to surface from its suppression by colonialism and Christianity (VEJA mentorship session, February, 2016). Both facilitators and participants welcomed indigenous spiritual knowledge into the educational process.

On a personal level, the VEJA case challenged me to be more open about 'unscientific' knowledge systems that influence my work, among them my Buddhist practice, my reading of mythology, my interest in consciousness, my socialist values, insights from science fiction and the voice of my body moving. Taryn Pereira, another facilitator on the course, has spoken about how the work of the Changing Practice participants has changed the way she sees rivers and nature as a whole. She now finds it difficult in her professional work to call a river a resource, the way she was trained to as an environmental scientist. These examples also highlight how absenting the absence of other forms of 
knowledge at the level of material interaction with nature lead to changes at the level of the embodied personality and a willingness to engage in scholarship and education as an activist practice.

4.1.2. What Did We Absent at the Level of Being in Relation to One Another through the Changing Practice Course and the VEJA Change Project?

Carpenter and Mojab [8] critique critical-educational theory as being locked into abstracted frames of culture that lack grounding in the materiality of the social world. This is counteracted or absented through a materialist analysis and revolutionary praxis that sees dialectics as a way of thinking about social life as relationships which emerge historically in the everyday [8]. For example, integrated water resource management and the constitution of South Africa call for the participation of all stakeholders in the decentralized management of rivers. This is an abstract concept that, as VEJA's case reveals, does not really occur in practice. Government officials speak to the law and the constitution without understanding how historical inequalities around water, combined with the current policy and law, affect people in their daily lives.

The VEJA participants navigated the bureaucracy of government departments by understanding the contradictions between policy and practice, and by being open to engagement while remaining clear in their intentions. They understood the historical nature of water governance relationships and how knowledge could become extracted from context. They understood that any relationship to knowledge requires ethical positioning and an expansive view of what it means to be human. They motivated us as facilitators to be willing to hear painful realities, open up to the historical and political reasons for contradictions, and assist participants in building these arguments into their change projects.

Through their well-articulated change project, VEJA was able to catalyse important alliances both with the formal traditional healer associations and with officials within the Department of Water and Sanitation. Although the DWS did not respond adequately as an institution, individuals within the department were touched by the evidence that was presented to them. It connected them to the African heritage which lay beneath their roles as civil servants. The evidence-based stories of the change projects enabled this.

4.1.3. What Did We Absent at the Level of Structure through the Changing Practice Course and the VEJA Change Project?

Neither VEJA nor the Changing Practice facilitators can claim we made any significant change in policy or even any difference to the ongoing devastation of the Vaal River, which is still the most polluted ecosystem in the country. Such massive changes can only be made through multiple networks of resistance and well-coordinated political action over long periods of time. We were however able to focus on one of the factors that inhibit such changes, namely professional institutions.

Professional institutions find it hard to engage meaningfully with activists or see their knowledge as valuable. As facilitators educated in these same institutions, we are continually attempting to encourage universities and well-resourced NGOs to reach out to participants. While some individuals in some institutions have collaborated enthusiastically with activists, for the most part, these institutions have viewed activists and community members as liabilities, people to be 'trained' or 'educated', or simply not related to at all. Where there has been participation, it has been mostly tokenistic, designed by researchers or government officials who see civil society activists as countable physical bodies who are expected to be present and participate without any compensation while professionals receive salaries for their participation.

One of the difficult moments for us as facilitators was witnessing how NGOs and other professional institutions only took activists' work seriously once they saw their work in a form recognisable to them as valuable, i.e., publications. The Changing Practice courses publish change project case booklets at the end of each course, and it was often only after seeing such publications that these institutions took notice-sometimes after many months of difficult work of trying to set up relationships with 
them [53]. If activists had published their work in their own language, or as a praise song, or as a drama, these forms would most likely not have had the same effect.

The publishing of the change project booklets was simultaneously a moment of great pride and of much sadness. Or perhaps it was a lesson in cognitive justice, or in this case, injustice. The response was a forceful reminder of how professional institutions judge knowledge to be valuable, despite the fact that the transdisciplinary research and practice currently in vogue in these institutions calls for an engagement with multiple knowledge systems-multiple, both in the sense of knowledge being drawn from different academic disciplines, as well as knowledge generated outside institutions.

This experience is an example of how the value supposedly given to 'other knowledges' tends to remain at the level of abstract theory. The reasons for this abstraction are explained by Carpenter and Mojab ([3] p. 27), who point out that innovative approaches and methodologies theorise "notions of social change and social justice" in a way that obscures the history and practices behind these notions. It is only when professional institutions are able to find tools to address "the real, contradictory social relations of exploitation and violence that are present in everyday life" ([8] p. 29) that we are likely to see a breaking down of the commodification and colonisation of knowledge. One such tool is the praxis of cognitive justice underscored by critical realism.

VEJA's change project affected the structure of the Changing Practice course in two significant ways:

(a) As facilitators we became more sensitive to different knowledge systems, both through the way we interacted with participants and in the way we reflected on our own practice. Participants were emboldened by the way their own knowledge was given centre stage, and this developed trust and confidence between us. It did not remove historical inequalities, but it did allow us to find a different way of being and working together.

(b) Thandiwe's brave confrontation with the experience of sexual harassment made us realise that, as activist-researchers and educator-activists, we needed to address head-on the relations between men and women. This led to serious discussions on gender with the South African Water Caucus, which resulted in gender equality being added to the SAWC principles and a working document being produced on gender and water. It also led to our decision to introduce gender dialogues into all follow-up Changing Practice courses.

\subsubsection{What Is Catalysed by Changes at the Level of the Embodied Personality?}

Speaking for myself, understanding knowledges as living systems existing in collective networks of beings, enhanced my confidence in the path I was walking. Often, in a university environment, I feel half-human, my body and spirit left at the door as I sit in a lecture hall or at a conference. The Changing Practice course participants, generous with their understanding of what it means to be knowing and caring beings in the world, encouraged me to challenge my limited view of education and gave me confidence to reside in a heartfelt space of vulnerability and care as an educator. The increase in my confidence to acknowledge the spiritual and local knowledge of the participants also led to an increase in their confidence to challenge me, as they witnessed how their ideas were changing my practice as an educator.

The VEJA change project enabled us to reassess relationships between participants and facilitators. One of the participants became a mentor on the next Changing Practice course and continues to champion space for indigenous knowledge practices. For myself, a learner in this space as much as anyone else, I was being asked to see a river as a spiritual being, and to reconsider my whole environmentalist training. Are we managers and governors of a resource, or co-inhabitors with it, along with the other rivers of the earth? Emboldened by African spirituality, I found the strength to ask myself what rivers can teach me before I presume to teach others about rivers.

\section{Conclusions}

VEJA's research showed how environmental and social justice is integrally linked to cognitive justice. It showed that the knowledge held within African spirituality provides a way of relating 
to a river as a living system central to a community's well-being. This is not new. Anthropologists, sociologists, poets, deep ecologists, eco-feminists, and environmentalists have described the intimate relationships that indigenous people have with nature. The difference for us was that VEJA brought this knowledge to the fore through radically absenting the absences of civil society participation in their own context, and drawing on their everyday attempts to bring about a change to the devastated landscape that they live in. They insisted on a process of honouring spiritual practices as an important reason for fighting for a cleaner river. They argued convincingly that African spiritual knowledge has something significant to offer water governance. Their work went to the very core of how rivers are valued and which voices get included or excluded as a result. They exposed the way in which current water governance and water policy in South Africa embraces a technicist view that inhibits us from knowing that rivers, and the whole living environment, are integral to our being alive in the world. Their arguments demand that we get to the root cause of our environmental crisis. Their ability to do this was enabled through their participation in the Changing Practice course and by prioritizing activists concerns as the hub of learning.

Using a critical realist epistemological dialectic $[40,43]$ (with a strong focus on the historical and material [8]), and viewing the VEJA change project as transformative social action, we can clearly see its value and the transformational capacity that this approach enabled. It is both a catalyst for transformational change within VEJA's context, and at the same time a catalyst for learning praxis for future change projects and future Changing Practice courses. It showed how transformative learning as cognitive justice could be made possible by situating the learning process within the historical and material realities of the participants and facilitators, taking in the differences and inequalities of their education, knowledge and learning [3]. The concept of learning together, which is so central to social learning, was actualized through a careful engagement with the generative concept of cognitive justice. Therefore, I would argue that paying attention to cognitive justice as learning praxis facilitates and supports the transgressive labour that activists engage in. It is care work that otherwise tends to go unrecognized and undervalued [22,23].

The facilitators, who had iteratively designed the course process to respond to contextually embedded emerging contradictions, went through their own social learning experience. The adoption of an overt emancipatory pedagogy, shared with participants and in response to their work, helped us to work with the generative concept of cognitive justice.

In conclusion, I return to the two questions raised by Jickling and Wals [7] when considering whether education is transformative: "What kind of education are we speaking of?" and "For what purpose?" Engaging with these two questions is an ongoing reflexive praxis which generates knowledge for participants within their own communities while also generating knowledge about how we learn. Seeing this happen in real time, and being able to reflect and adapt to it, was made possible by viewing the whole process of learning as anchored in the historical and material $[3,40,43]$ contexts, with all its contradictory social and environmental relations. This is what led us to engage in cognitive justice issues which expanded both facilitators' and participants' understanding of environmental issues and learning practices.

The flexible yet rigorous combination of approaches allowed us to weave what was coming out of the change projects back into the course without side-stepping or avoiding issues as they arose. Nobody objected that gender violence or the politics of knowledge were not directly relevant to environmental learning, and the more we engaged with these core issues, the more we realized how they were interwoven with the environmental problems we faced. Ultimately the Changing Practice course is itself a change project with the aim of learning about learning as an environmental activist practice. If the purpose of education is to approach knowledge as living systems, as collective networks in relation to the self, each other, and the planet, it can be done.

Funding: This research was partly funded by the International Social Sciences Council as part of the T-learning Knowledge Network, and by the Water Research Commission. 
Acknowledgments: Special acknowledgement to Samson Mokoena, Mduduzi Tshabalala and Thandiwe Ngcanga who gave me permission to use their change project work as a case in this paper. I would like to acknowledge the Changing Practice coalition: Stella Horgan, Thabo Lusithi, December Ndlhovu, Taryn Pereira and Jessica Wilson as well as all the participants of the Changing Practice courses. I would also like to acknowledge the writing and editorial teachings of my dear friend, Robert Berold, and my supervisors: Distinguished Heila Lotz-Sisitka, Leigh Price and Tally Palmer. Finally, a big thanks to my two communities of practice- 'the Goats and Gogos' and 'the Fourth Leap'.

Conflicts of Interest: The authors declare no conflict of interest.

\section{References}

1. Wilson, J.; Victor, M.; Burt, J.; Pereira, T.; Ngcozela, T.; Ndhlovu, D.; Ngcanga, T.; Tshabalala, M.; James, M. Citizen Monitoring of the NWRS2; Water Research Commission: Tshwane, South Africa, 2016.

2. Burt, J.; Lotz-Sisitka, H.; Rivers, N.; Berold, R.; Ntshudu, M.; Wigley, T.; Stanford, R.; Jenkin, T.; Buzani, M.; Kruger, E. The Role of Knowledge in a Democratic Society: Investigations into Mediation and Change-Oriented Learning in Water Management Practices; Water Research Commission: Tshwane, South Africa, 2014.

3. Carpenter, S.; Mojab, S. Revolutionary Learning: Marxism, Feminism and Knowledge; Pluto Press: London, UK, 2017.

4. Tshabalala, M.; Thandiwe, N.; Samson, M. Water and Tradition; Environmental Monitoring Group: Cape Town, South Africa, 2016.

5. Friends of the Earth Europe. Overconsumption? Our Use of the World's Natural Resources. 2009. Available online: https://cdn.friendsoftheearth.uk/sites/default/files/downloads/overconsumption.pdf (accessed on 22 July 2019).

6. Orr, D.W. Earth in Mind: On Education, Environment, and the Human Prospect; Island Press: Washington, DC, USA, 2004.

7. Jickling, B.; Wals, A.E.J. Debating education for sustainable development 20 years after Rio: A conversation between Bob Jickling and Arjen Wals. J. Educ. Sustain. Dev. 2012, 6, 49-57. [CrossRef]

8. Vygotsky, L.S. Mind in Society: The Development of Higher Psychological Processes; Harvard University Press: Cambridge, MA, USA, 1980.

9. Warmington, P.; Daniels, H.; Edwards, A.; Brown, S.; Leadbetter, J.; Martin, D.; Middleton, D.; Parsons, S.; Popova, A. Surfacing contradictions: Intervention workshops as change mechanisms in professional learning. In Proceedings of the British Education Research Association Annual Conference, Pontypridd, UK, 14-17 September 2005.

10. Engestrom, Y. Enriching the theory of expansive learning: Lessons from journeys toward coconfiguration. Mind Cult. Act. 2007, 14, 23-39. [CrossRef]

11. Hall, B.L.; Clover, D.E.; Crowther, J.; Scandrett, E. Learning and Education for a Better World: The Role of Social Movements; Sense Publishers: Rotterdam, The Netherlands, 2012.

12. Choudry, A. Learning Activism: The Intellectual Life of Contemporary Social Movements; University of Toronto Press: New York, NY, USA, 2015.

13. Choudry, A. (Almost) everything you always wanted to know about activist research but were afraid to ask: What activist researchers say about theory and methodology. Contention 2014, 1, 75-88.

14. Boughton, B. Popular Education and the 'party line'. Glob. Soc. Educ. 2013, 11, 239-257. [CrossRef]

15. Hursh, D.; Henderson, J.; Greenwood, D. Environmental education in a neoliberal climate. Environ. Educ. Res. 2015, 21, 299-318. [CrossRef]

16. Choudry, A. Transnational activist coalition politics and the de/colonisation of pedagogies of mobilisation: Learning from anti -neoliberal indigenous movement articulations. Int. Educ. 2007, 37, 97-112.

17. Darder, A. Neoliberalism in the academic borderlands: an on-going struggle for equality and human rights. Educ. Stud. 2012, 48, 412-426. [CrossRef]

18. Giroux, H.; Samalavicius, A. Higher education and neoliberal temptation. Kult. Barai 2016, 4, 1-5.

19. Salleh, A. From metabolic rift to "metabolic value": Reflections on environmental sociology and the alternative globalization movement. Organ. Environ. 2010, 23, 205-219. [CrossRef]

20. Salleh, A. Ecofeminism as Politics: Nature, Marx and the Postmodern, 2nd ed.; Zed Books: London, UK, 2017. 
21. Lotz-Sisitka, H.; Ali, M.B.; Mphepo, G.; Chaves, M.; Macintyre, T.; Pesanayi, T.; Wals, A.; Mukute, M.; Kronlid, D.; Tran, D.T.; et al. Co-designing research on transgressive learning in times of climate change. Curr. Opin. Environ. Sustain. 2016, 20, 50-55. [CrossRef]

22. Burt, J.; Pereira, T.; Lotz-Sisitka, H. Entering the Mud: Transformative Learning and Cognitive Justice as Care Work. Unpublished Article, Latest Draft 3 December 2018. Available online: https://www.researchgate.net/publi cation/330115056_Entering_the_mud_Transformative_learning_and_cognitive_justice_as_care_work (accessed on 3 April 2019).

23. Burt, J.; James, A.; Walters, S.; von Kotze, A. Working for living: Popular education as/at work for social-ecological justice. S. Afr. J. Environ. Educ. in press.

24. Visvanathan, S. Knowledge, justice and democracy. In Science and Citizens: Globalization and the Challenge of Engagement; Leach, M., Scoones, B., Wynne, B., Eds.; Zed Books: London, UK, 2005; pp. 83-96.

25. Chan-Tiberghien, J. Towards a 'global educational justice' research paradigm: Cognitive justice, decolonizing methodologies and critical pedagogy. Glob. Soc. Educ. 2004, 2, 191-213. [CrossRef]

26. Santos, B.D.S. Epistemologies of the South: Justice Against the Epistemicide; Routledge: London, UK, 2016.

27. Santos, B.D.S. Beyond abyssal thinking. Binghamt. Univ. Rev. 2007, 30, 45-89.

28. Kincholoe, J. Knowledge and Critical Pedagogy: An Introduction; Springer: London, UK, 2008.

29. Nyamnjoh, F.B. Potted plants in greenhouses': A critical reflection on the resilience of colonial education in Africa. J. Asian Afr. Stud. 2012, 47, 129-154. [CrossRef]

30. Quaye, S.J. Voice of the researcher: Extending the limits of what counts as research. J. Res. Pract. 2007, 3, M3.

31. Todd, S. Learning from the Other; State University of New York: New York, NY, USA, 2003.

32. Davies, C.J. Whose Knowledge Counts? Exploring Cognitive Justice in Community-University Collaborations. Ph.D. Thesis, University of Brighton, Brighton, UK, 2016.

33. Bennett, K. Towards an epistemological monoculture: Mechanisms of epistemicide in European research publication. Engl. Sci. Res. Lang. Debates Discourses 2015, 2, 9-36.

34. Bennett, K. The transparency trope: Deconstructing english academic discourse. Discourse Interact. 2015, 8, 5-19. [CrossRef]

35. Burt, J.; Pereira, T.; Lusithi, T.; Horgan, S.; Ndlhovu, D.; Wilson, J.; Munnik, V.; Boledi, S.; Jolobe, C.; Kakaza, L.; et al. Changing Practice: Olifants Catchment Final Report; Environmental Monitoring Group: Cape Town, South Africa, 2018.

36. Munnik, V.; Burt, J.; du Toit, D.; Price, L. Report on the Forum of Forums; Water Research Commission: Tshwane, South Africa, 2016.

37. Price, L. Some implications of MetaReality for environmental educators. In Critical Realism, Environmental Learning and Socio-Ecological Change; Price, L., Lotz-Sisitka, H., Eds.; Routledge: Oxford, UK, 2016; p. 340.

38. Burt, J.; James, A.; Price, L. A peaceful revenge: achieving structural and agential transformation in a South African context using cognitive justice and emancipatory social learning. J. Crit. Realism 2018, 17, 492-513. [CrossRef]

39. Bhaskar, R. Enlightened Common Sense: The Philosophy of Critical Realism; Hartwig, M., Ed.; Routledge: Oxford, UK, 2016.

40. Bhaskar, R. Dialectic: The Pulse of Freedom; Routledge: Oxford, UK, 2008.

41. Bhaskar, R. Scientific Realism and Human Emancipation; Routledge: Oxford, UK, 2009.

42. Bhaskar, R.; Scott, D. A Theory of Education; Springer: London, UK, 2015.

43. Price, L. Caring, healing and befriending: An interdisciplinary critical realist approach to reducing oppression and violence against women in Southern Africa. In Critical Realist Reading Group, Institute of Education; University College London: London, UK, 2015.

44. Bhaskar, R. A Realist Theory of Science; Routledge: Oxford, UK, 2008.

45. Bhaskar, R. The Possibility of Naturalism; Routledge: Oxford, UK, 2005.

46. Hartwig, M. Dictionary of Critical Realism; Routledge: Oxford, UK, 2007.

47. Olvitt, L.L. Education in the anthropocene: Ethico-moral dimensions and critical realist openings. J. Moral Educ. 2017, 46, 396-409. [CrossRef]

48. Hallowes, D.; Munnik, V. The Destruction of the Highveld Part 1: Digging Coal; GroundWork: Pietermaritzburg, South Africa, 2016.

49. Ndlhovu, D.; Mashile, A.; Mdluli, P. Saving Moholoholo; Environmental Monitoring Group: Cape Town, South Africa, 2015. 
50. Fricker, M. Epistemic Injustice: Power and Ethics of Knowing; Oxford University Press: Oxford, UK, 2007.

51. de Sousa Santos, B. The World Social Forum and the global left. Politics Soc. 2008, 36, 247-270. [CrossRef]

52. Visvanathan, S. Alternative science. Theory Cult. Soc. 2006, 23, 164-169. [CrossRef]

53. Bernard, P. “Living water” in Nguni healing traditions, South Africa. Worldviews 2013, 17, 138-149. [CrossRef]

(C) 2019 by the author. Licensee MDPI, Basel, Switzerland. This article is an open access article distributed under the terms and conditions of the Creative Commons Attribution (CC BY) license (http://creativecommons.org/licenses/by/4.0/). 